A N N A L ES

UNIVERSITATIS MARIAE CURIE-SKŁODOWSKA

LUBLIN - POLONIA

VOL. LXVI, 2

SECTIO G

2019

Uniwersytet w Białymstoku

KAROL KUŹMICZ

k.kuzmicz@uwb.edu.pl

ORCID: 0000-0002-3914-5499

\title{
Pokój jako element ideowy myślenia utopijnego
}

Peace as an Ideological Element of the Utopian Thinking

Niechaj więc wpaja się wszystkim obywatelom przekonanie, że wojna jest największym po zagładzie rzeczypospolitej nieszczęściem, pokój zaś największym po praworządności dobrem.

G.B. de Mably, Zasady praw (1776)

\section{WPROWADZENIE}

Biorąc pod uwagę niezaprzeczalny fakt, iż wojny w znaczący sposób wpływały na przemiany ustroju, prawa i myśl polityczną, na wstępie proponuję zgoła odmienny sposób rozumowania, według którego na to, jak wyglądały wojny, oddziaływały rozmaite czynniki, w tym wszystkie wyżej wymienione, czyli ustrój, prawo i myśl polityczna. W tym właśnie kontekście postrzegam rozwój myśli utopijnej, wskazując, że zdecydowanie i w wielu aspektach oddziaływała ona na wojny, zarazem eksponując jednak aksjologiczną wartość pokoju. Można nawet powiedzieć, że utopie społeczne stanowiły pewnego rodzaju intelektualny poligon (przynajmniej teoretyczny) dla zastosowania w przyszłości nowatorskich instytucji prawnych, reform o charakterze społecznym, politycznym i ekonomicznym czy wreszcie pojawienia się i rozwoju wielu gałęzi prawa, w tym prawa wojennego, początkowo związanego z ius gentium, a obecnie funkcjonującego w ramach prawa międzynarodowego publicznego.

1 G.B. de Mably, Zasady praw, t. 1, Kraków 1952, s. 232. Zob. także: Utopia walczaca, wyb. i oprac. R. Brandwajn, Warszawa 1962, s. 111. 
Formułując tytuł niniejszego artykułu, celowo zdecydowałem się wskazać na pokój, a nie na wojnę, jako element ideowy myślenia utopijnego. Słusznie odróżnia się utopie pozytywne od negatywnych - w tym drugim przypadku należałoby wyeksponować właśnie wojnę, zaznaczając, że jest ona elementem świata antyutopijnego. To wojna bowiem stanowi ideologiczny sens istnienia utopii społecznych w wersjach negatywnych, w których wojny toczą się właściwie permanentnie, w których szuka się bądź kreuje wrogów zarówno zewnętrznych, jak i wewnętrznych, prawdziwych i wyimaginowanych. Należy podkreślić, że to strach (a nie odwaga) decyduje o ich sile oraz o tym, że utopie negatywne stają się bardziej popularne niż ich wersje pozytywne. Pomogły w tym przede wszystkim dwudziestowieczne doświadczenia totalitarne, które niestety okazały się prawdziwymi horrorami wzbudzającymi i potęgującymi strach. Był on uzasadniony, ponieważ stanowił warunek sine qua non zarówno dla pojawienia się antyutopii, jak i dla funkcjonowania systemów totalitarnych i ich okrucieństw.

Choć dochodzi do wojen w utopiach, to zdecydowanie celem życia w nich jest pokój, który stanowi niezaprzeczalną wartość, podobnie jak np. odwaga, patriotyzm czy poświęcenie. W tym kontekście można powiedzieć, że utopie nie są pacyfistyczne, lecz na pewno należy je uznać za pacyfizujące ${ }^{2}$. Dzieje się tak dlatego, że: 1) opisy wojen należą zazwyczaj do jednych z najbardziej realistycznych, ponieważ bardzo przypominają rzeczywistość; 2) wojny przedstawiane w utopiach są zawsze prowadzone na ściśle określonych zasadach, według ustalonych strategii, są w nich respektowane pewne reguły i zwyczaje (zwykle odmienne od tych stosowanych w świecie realnym). Utopie zawierają zatem silne przesłanie edukacyjne, dlatego również w przedmiocie wojny mogą nas czegoś nauczyć (np. może to być przesłanie dotyczące humanitarnego traktowania pokonanych i jeńców wojennych, udziału w wojnach kobiet, rozmaitych ćwiczeń i wychowania patriotycznego, w tym odpowiedniego przygotowania mentalnego i fizycznego w zakresie prowadzenia działań zbrojnych); 3) możliwości kreacyjne, jakie dają utopie, sprawiają, że są one polem do popisu dla pomysłowości ich autorów do zaprezentowania najczęściej niezwykłych rodzajów uzbrojenia wojskowego, różnego rodzaju maszyn, urządzeń, fortyfikacji i budowli o charakterze militarnym, znacznie przewyższających możliwości technologiczne swoich czasów.

\section{SUNT ET BELLI PACIS IURA - W UTOPIACH WOJNA I POKÓJ MAJĄ SWOJE PRAWA}

W pewnym sensie (zwłaszcza historiozoficznym) pokój można uznać za marzenie, a na pewno za coś, czego bardzo często ludziom brakowało, co jeśli nawet było, to niestety miało swój kres. Właściwie nieodłącznym elementem historii

2 Zob. Pacyfizm czy zagłada, red. M. Szyszkowska, Warszawa 1996; Pacyfizm. Prawo a dzieje państwa i ustroju, red. M. Szyszkowska, t. 2, Białystok 2001. 
ludzkości są wojny przeplatane okresami dłuższego bądź krótszego pokoju lub odwrotnie - pokoju przeplatanego okresami wojen. Starożytni Grecy uznawali wojnę za naturalną konieczność, a nawet za pewnego rodzaju fatum, czyli nasze ludzkie przeznaczenie. Tak jak walka toczy się nieustannie w świecie przyrody, tak też walka trwa między ludźmi. Już w okresie rozwoju jońskiej filozofii przyrody Heraklit z Efezu twierdził, że ,przeciwstawne łączy się, [a] z niezgodności - najpiękniejsza zgodność i wszystko następuje przez walkę"3 oraz że to „wojna jest ojcem wszechrzeczy i wszystkich rzeczy królem. Jednych przedstawia jako bogów, innych jako ludzi, jednych czyni niewolnymi, drugich wolnymi"4. Wojna była ujmowana przy tym nie tylko jako niszczycielska siła, lecz przede wszystkim jako siła twórcza potęgująca zmianę, warunkująca rozwój, a nawet wprowadzająca postęp.

Z kolei rzymska koncepcja była zupełnie inna, ponieważ za naturalny uważała pokój (pax), a wojnę traktowała jedynie jako środek prowadzący do jego ustanowienia. Chodzi tutaj zwłaszcza o koncepcję pax Romana ${ }^{5}$, która w założeniach nie była utopią, lecz się nią stała. Największym paradoksem wprowadzania pokoju rzymskiego był fakt prowadzenia wojen - najpierw w celu rozszerzania granic Imperium Rzymskiego, a następnie po to, by go utrzymać. Rzymianie jako realiści doskonale jednak zdawali sobie sprawę z tego, że podczas wojny milkną prawa (Inter arma silent leges), w związku z czym sami okazywali szacunek dla prawa, domagając się tego, aby również wojna w końcu ustąpiła przed togą (Cedant arma togae!) ${ }^{6}$.

W powyższym kontekście można mówić o doktrynach prawnych i politycznych głoszących konieczność uregulowania czy też unormowania działań w czasie konfliktów zbrojnych. Chodzi tutaj głównie o rozwój prowadzący do ukształtowania się współczesnego prawa międzynarodowego publicznego, w ramach którego pojawiły się jako realnie związane z polityką międzynarodową takie prawa szczegółowe, jak: prawo wojenne, prawo dyplomatyczne i konsularne, prawo traktatowe, prawo morskie itp. Wśród myślicieli mających wpływ na ich powstanie należy wymienić greckich sofistów oraz Platona i Arystotelesa, a także najważniejszych chrześcijańskich propagatorów teorii wojny sprawiedliwej, takich jak św. Augustyn z Tagesty (354-430), św. Rajmund z Penyafortu (1185-1275) czy św. Tomasz z Akwinu (1225-1274), oraz nowożytnych filozofów zajmujących się prawem natury i prawem narodów, do których obok najważniejszego chyba Hugo Grocjusza (1583-1645) można dodać chociażby Baltazara de Ayalę (1548-1584), Albericusa Gentilisa (1552-1608) i Francisco Suareza (1548-1617). Wśród Polaków zajmujących się problematyką wojny i pokoju, którzy zyskali międzynarodową sławę i szacunek, znajdują się prawnicy z Akademii Krakowskiej: Stani-

3 Cyt. za: R. Palacz, Klasycy filozofii, Warszawa 1988, s. 24.

Ibidem, s. 26.

Por. H. Izdebski, Historia myśli politycznej i prawnej, Warszawa 2001, s. 28.

6 Cicero, De Officiis (O powinnościach), [w:] idem, Pisma filozoficzne, t. 2, Warszawa 1960, I, 22. 
sław ze Skarbimierza i reprezentujący Królestwo Polskie w sporach z Zakonem Krzyżackim Paweł z Włodkowic (około 1370-1435) oraz renesansowy myśliciel polityczny Andrzej Frycz Modrzewski (1503-1572), którego częścią z trzech dopuszczonych do druku w naszym kraju ksiąg Rozważań o naprawie Rzeczypospolitej w pięciu księgach (Commentariorum de Republica emendanda libri quinquez) z 1551 r. była księga $O$ wojnie (De bello). $\mathrm{Z}$ tej ostatniej pochodzi znamienny cytat mówiący o tym, że ,żadne korzyści z wojny nie są tak wielkie, aby mogły jej szkodom dorównać [...]"ᄁ. Ponieważ myśl utopijna stanowi integralną część nowożytnej myśli politycznej i prawnej, nie można w tym zakresie pominąć zasług utopistów, zwłaszcza tych renesansowych, którzy również przyczynili się do tego, że wojna stopniowo zaczęła otrzymywać swoje prawa. W związku z tym zaczęły się pojawiać propozycje stopniowania pokoju w kontekście jego realności. Wśród rodzajów pokoju (pax) wskazywano najczęściej na pokój w rodzinie (pax domestica), w państwie (pax civilis) i na świecie (pax terrena), które nie były uznawane za utopijne, lecz były możliwe do wprowadzenia. Natomiast za najbardziej utopijne bądź niezwykle trudne do zrealizowania traktowano odmiany pokoju powszechnego (pax universalis) i pokoju wiecznego (pax perpetuela). Przykładami tego ostatniego są dwa oświeceniowe projekty. Pierwszy to Projet pour rendre la paix perpétuelle en Europe duchownego francuskiego Karola Ireneusza Castel de Saint-Pierre'a z 1713 r., a drugi to Traktat o wiecznym pokoju Immanuela Kanta z 1795 r. Przesłaniem pierwszego z nich była wizja pokoju opartego nie na równowadze sił w Europie, lecz na hegemonii i przywództwie jednego ośrodka centralnego, do którego oczywiście pretendowały potęgi europejskie, w tym osiemnastowieczna Francja. Z kolei projekt Kantowski, który obecnie nie przez wszystkich jest uznawany za utopijny, lecz raczej za traktat o charakterze prawno-politycznym będący w fazie realizowania, zakładał wprowadzanie wiecznego pokoju na podstawie realizacji sformułowanych w nim artykułów. Kant uwzględnił m.in. sześć artykułów przygotowawczych (jak sam to określił, są to „przygotowawcze artykuły do wiecznego pokoju między państwami”) oraz trzy artykuły definitywne, mówiące o konieczności wprowadzenia: 1) federacyjnego związku państw; 2) ustroju republikańskiego; 3) prawa kosmopolitycznego ${ }^{8}$. W powyższym kontekście można powiedzieć, że projekt wiecznego pokoju Kanta, nawet jeśli się nie spełni, to nadal pozostaje ze swoimi (zwłaszcza tymi niezrealizowanymi do końca) artykułami ideą jednoczącą ludzkość 9 .

7 A. Frycz Modrzewski, O poprawie Rzeczypospolitej, [w:] idem, Dzieła wszystkie, t. 1, Warszawa 1953, s. 43.

8 Por. I. Kant, Wieczny pokój, Torun 1992, s. 22 i n.

9 Zob. K. Kuźmicz, Kantowska koncepcja wiecznego pokoju jako przykład idei jednoczacej ludzkość, [w:] Wielokulturowość polskiego pogranicza. Ludzie - idee - prawo, red. A. Lityński, P. Fiedorczyk, Białystok 2003, s. 411-418. 


\section{PAX OPTIMA RERUM - W UTOPIACH POKÓJ JEST RZECZĄ NAJLEPSZĄ}

Wraz z pojawieniem się pierwszych utopii typu renesansowego ich autorzy starali się pokazać, że świat może być nie tylko inny, niż jest, lecz także to, że może być od niego lepszy. W zasadzie większość z nich przedstawiała wizje idealnego życia ludzi - takiego, jakie być powinno. Pojawienie się w 1516 r. Książeczki zaiste złotej i niemniej pożytecznej jak przyjemnej o najlepszym ustroju państwa i nieznanej dotąd wyspie Utopii Tomasza Morusa (1478-1535) wytyczyło cele zarówno dla następnych utopii społecznych, jak i dla właściwego modelu życia wspólnotowego ludzi, wśród których znajdował się pokój jako wartość ponadczasowa i uniwersalna. Jednakże ani Utopia Morusa, ani Miasto słońca Tomasza Campanelli (1568-1639) czy Nowa Atlantyda Francisa Bacona (1561-1626) nie są pacyfistyczne, czyli zupełnie wolne od wojen i tego, co militarne. Wręcz przeciwnie, zgodnie z rzymską sentencją mieszkańcy utopii zdają sobie sprawę z tego, że jeśli chcą żyć w pokoju, to muszą być przygotowani do wojny ${ }^{10}$ - i to $\mathrm{w}$ najlepszy z możliwych sposobów, który ma im zagwarantować zwycięstwo ${ }^{11}$. W tym celu, po pierwsze, w znakomity sposób wykorzystują warunki naturalne, takie jak położenie geograficzne i przestrzenne, klimat, ukształtowanie terenu itp. Szczególnie cenione są przestrzenie trudno dostępne, ukryte zazwyczaj gdzieś na morzach i oceanach. Po drugie, jednym z najważniejszych obowiązków mieszkańców utopii, o charakterze powszechnym, jest obrona ojczyzny. Do wojny przygotowywani są w zasadzie wszyscy od najmłodszych lat - w tym celu ćwiczą i uczą się rzemiosła wojennego, a zadania są wyznaczane odpowiednio do zdolności, wieku, płci i doświadczenia. Po trzecie, dysponują nowoczesnymi technologiami wojskowymi (w tym uzbrojeniem, fortyfikacjami, taktykami i strategiami mającymi zapewnić przewagę nad każdym przeciwnikiem w ewentualnym boju) oraz podejmują działania mające na celu ich rozwój. Po czwarte, eksponują swoją siłę militarną, by zniechęcić do walki potencjalnych agresorów. Po piąte, posiadają przewagę informacyjną i mentalną (psychologiczną) nad przeciwnikiem, zawsze wiedzą więcej na temat innych państw i ludów. Po szóste, jeśli dochodzi do wojny, prowadzą ją skutecznie, szybko i bezwzględnie do końca, którym ma być ich całkowite zwycięstwo. Dzięki temu ustalają (czy raczej dyktują) warunki pokoju, który - jak wszystko w utopiach - jest związany z porządkiem, harmonią i spokojnym ładem ${ }^{12}$.

Co ciekawe, wskazując powyższe cechy, można zauważyć, że nawet utopie pozytywne w zakresie wychowania, przygotowań i prowadzenia wojen przypomi-

${ }_{10}$ Igitur qui desiderat pacem, praeparet bellum, bardziej znane jako Si vis pacem para bellum - Wegecjusz, De re militari, III, www.thelatinlibrary.com/vegetius3.html [dostęp: 21.10.2018].

11 Sun Tzu, Sztuka wojny, Warszawa 2009, s. 32.

12 Pax est tranquillitas ordinis. Zob. Sentencje łacińskie, oprac. M. Dubiński, Warszawa 2005, s. 517. 
nają totalitaryzmy, w których eksponuje się przecież rolę armii, a polityka wojnę traktuje jako swoje bardzo skuteczne narzędzie wykorzystywane do osiągnięcia zamierzonych celów. Różnicą podstawową jest jednak to, że w utopiach negatywnych wojna stanowi istotny, stały i nieodłączny element ich funkcjonowania. Nie ma poczucia bezpieczeństwa ani zewnętrznego, ani wewnętrznego, za to panuje wszechogarniający strach, wyczuwalne są wrogość i brak zaufania do kogokolwiek. W antyutopiach pokój jest w zasadzie nieosiągalny, a gdyby nawet był, to - w przeciwieństwie do wojny - utrudniałby sprawowanie władzy.

W związku z tym cechą wspólną wszystkich utopii pozytywnych jest fakt uznający wojny za niemoralne i sprzeczne $\mathrm{z}$ istotą życia $\mathrm{w}$ nich jako krainach szczęścia. Wskazywali na to już pierwsi utopiści, uznający wojny - związane z użyciem siły zbrojnej, czyli przemocy, nawet w sensie prowadzenia działań jedynie obronnych - przynajmniej za mniejsze, ale jednak zło. Przedstawiane w utopiach krainy, mimo że z założenia nie dążyły do wojny, to wcale ich nie unikały, zresztą podobnie ,jak my w Polsce [także mieszkańcy utopii nie znają] pojęcia pokoju za wszelką cenę"13. Jeśli dochodzi do wojny, to jest ona uważana za tragedię, która dotyka nie tylko pokonanych, lecz także zwycięzców. Udział w niej jest zazwyczaj przedstawiany jako konieczność lub obowiązek, nigdy nie jest on podejmowany z niskich pobudek (np. dla zysków czy podbojów), lecz zawsze w imię wartości wyższych. Przykładowo według Morusa Utopianie za nieprzyjaciela uważają jedynie tego, kto wyrządził jakąś krzywdę, a do ważnych powodów wszczęcia wojny zaliczają: obronę własnych granic i pomoc sprzymierzeńcom oraz, „kierując się tylko względami ludzkości”, uwolnienie innych ludów od jarzma tyranii i cierpień pod rządami despotów ${ }^{14}$. Z kolei Campanella wskazywał, że Solariusze ,niekiedy, także ulegając uczuciu, postępują rozumnie, gdy np. w porywie słusznego gniewu wszczynają sprawiedliwą wojnę [...] przeciw gwałcicielom prawa naturalnego i religii”'15. Jednakże, prowadząc jakąkolwiek wojnę, utopie mają na względzie przede wszystkim jak najszybsze jej zakończenie i przywrócenie pokoju. Pisał o tym m.in. Stanisław Leszczyński (1677-1766) w wydanej po raz pierwszy anonimowo w 1752 r. Rozmowie Europejczyka z wyspiarzem z Królestwa Dumocala. Według niego w Europie rzadziej spotyka się władców, którzy są przyjacielami poddanych, niż tych, którzy „wojny prowadzą jedynie dla przymuszenia nieprzyjaciół do pokoju”16. Dlatego w szerszym kontekście utopijnych rozważań o wojnie i pokoju można zauważyć dwie

13 Cytat z mowy sejmowej wygłoszonej w dniu 5 maja 1939 r. przez Ministra Spraw Zagranicznych Rzeczypospolitej Polskiej Józefa Becka.

14 T. Morus, Utopia, Poznań 1947, s. 103.

15 T. Campanella, Miasto stońca, Wrocław 1955, s. 46.

16 S. Leszczyński, Rozmowa Europejczyka z wyspiarzem z Królestwa Dumocala, [w:] Rys życia i wybór pism Stanisława Leszczyńskiego króla polskiego xięcia Lotaryngii i Baru zwanego Filozofem Dobroczyńca, Warszawa 1828, s. 289. 
prawidłowości: 1) w utopiach, choć prowadzi się wojny, to jednak dąży się do pokoju; 2) utopie nie gloryfikują wojny, lecz cenią zwycięstwo. Utopiści zatem z jednej strony pokazywali świat, jaki ich zdaniem być powinien (czyli najlepiej bez wojen), z drugiej zaś krytykowali wojny jako niezbyt pasujące do obrazu miejsca dobrego i szczęśliwego (eu-topos).

\section{BELLA, HORRIDA BELLA! - UTOPIE O OKROPNOŚCIACH WOJNY}

Właściwie we wszystkich utopiach społecznych o charakterze pozytywnym można znaleźć wątki antywojenne. Już w pierwszej nowożytnej utopii społecznej, napisanej przez Morusa, ewidentnie widać, że „wojna jest dla Utopian potwornością [...] [i] wbrew mniemaniom większości narodów sądzą oni, że najmniej chluby przynosi państwom sława wojenna" ${ }^{17}$. Z kolei francuski filozof i polityk Gabriel Bonnot de Mably (1709-1785) w napisanych w 1758 r. Prawach $i$ obowiazkach obywatela stwierdzil, że „każda wojna jest jednakowo zgubna dla ludzkości”. Natomiast we wspomnianych już Zasadach praw z 1776 r., krytykując przelewanie krwi, dodał, że „krew ludzka jest dostatecznie cenna, by ją [jednak - K.K.] oszczędzać". Ponadto Bonnot de Mably zaproponował, żeby spośród wszystkich wojen „napastniczą uznać za zbrodnię”"18, a ze wszystkich cnót uznać waleczność po sprawiedliwości za najbardziej cenioną cnotę $^{19}$ oraz by ,ustanowić specjalnych urzędników, których jedynym zajęciem byłoby utrzymanie pokoju"20.

Równie ciekawie relacja wojny i pokoju została przedstawiona przez Franciszka Fénelona (1651-1715) w Przypadkach Telemaka z 1775 r. W księdze piątej tego dzieła, gdy tytułowy bohater przebywał na Krecie, po śmierci legendarnego króla Minosa dokonywano elekcji nowego panującego, zadając każdemu z kandydatów trzy identyczne pytania ${ }^{21}$. Pierwsze dotyczyło tego, kogo można uznać za najbardziej wolnego człowieka. Telemak odpowiedział, że tego, kto potrafi zachować swobodę umysłu nawet w niewoli. W drugim pytano o to, kto jest najnieszczęśliwszym z ludzi. W odpowiedzi Telemak wskazał na króla, któremu tylko się wydaje, że jest szczęśliwy, a tak naprawdę nieszczęśliwymi czyni swoich poddanych. Wreszcie najważniejsze trzecie, ostatnie pytanie w kontekście wojny i pokoju sprowadzało się do tego, czy lepszy jest król wojownik i obrońca ojczyzny czy też może król umiejący rządzić państwem w pokoju. Zdanie Telemaka w tej kwestii było następujące:

17 T. Morus, op. cit., s. 103.

18 G.B. de Mably, op. cit., s. 229.

19 Ibidem.

20 Ibidem, s. 233.

21 F. Fénelon, Przypadki Telemaka Syna Ulisesa, Warszawa (Lipsk) 1775, s. 91-97. 
[...] wojownik sławą własną upojony prawie tak samo lud swój zwycięski, jak inne zwyciężone narody niszczy, bowiem kiedy się wszędzie wojenny ogień szerzy: prawa, rola i nauki niszczeją. Pan, co potrzebnych do pokoju nie ma przymiotów, poddanym swoim pożytku z szczęśliwie zakończonej wojny udzielić nie możè 22 .

Lepszy jest zatem władca, który mądrze uszczęśliwia naród swym panowaniem, ponieważ jeśli w pokoju jest sposobny rządzić, to zapewnia narodowi bezpieczeństwo wewnętrzne i potrafi go obronić od nieprzyjaciela ${ }^{23}$. Dokonując pewnego ogólnego podsumowania wszystkich recept podanych w tym dziele na temat idealnego władcy, należy podkreślić, że tylko ten, „kto świadom nieszczęść, trwóg i trudności wojennych daleko się ich lepiej niźli ten uchronić może, który żadnego w tym nie ma doświadczenia"24, oraz to, że zawarty pokój jest rzeczą świętą ${ }^{25}$.

Z kolei o okropnościach wojny, w porównaniu do błogości życia w pokoju, na przykładzie alpejskiego Clarens pisał w Nowej Heloizie Jean-Jacques Rousseau (1712-1778):

Widziałem okropny pożar całego miasta bez odporu i obrońców. Takie jest prawo wojny uznane między narodami Europy, mądrymi, ludzkimi i ogładzonymi. Nie wystarcza im wyrządzanie nieprzyjacielowi wszystkiego zła, z którego ciągną korzyść, ale liczą za korzyść wszystko zło, jakie mu można niepotrzebnie wyrządzićé ${ }^{26}$.

Natomiast bitwę morską opisał słowami:

Widziałem, jak na szerokim Oceanie, gdzie się powinno z taką przyjemnością spotykać innych ludzi, dwa duże okręty szukały się nawzajem, a znalazłszy się, napadły na siebie i biły się ze wściekłością, jak gdyby ta ogromna przestrzeń była dla każdego z nich za mała. Widziałem, jak rzygały na siebie żelazem i ogniem. Podczas dość krótkiej walki zobaczyłem obraz piekła ${ }^{27}$.

Utopia wspólnotowego życia w Clarens stała się chyba modelowym rozwiązaniem dla Szwajcarii, ojczyzny Rousseau, jako państwa, które swoją politykę międzynarodową prowadzi z jednej strony w gotowości do tylko jednego rodzaju wojny - w imię obrony swej wolności (suwerenności, niezależności). Natomiast $\mathrm{z}$ drugiej strony sama się odcina od świata zewnętrznego; nie angażuje się w żadne spory, sojusze czy przymierza, jest jednak gotowa zawsze i wszędzie, każdemu - bez względu na dzielące ich różnice - udzielić pomocy, by w sposób pokojowy rozwiązać, a najlepiej aby zakończyć wszystkie spory i konflikty (zwłaszcza

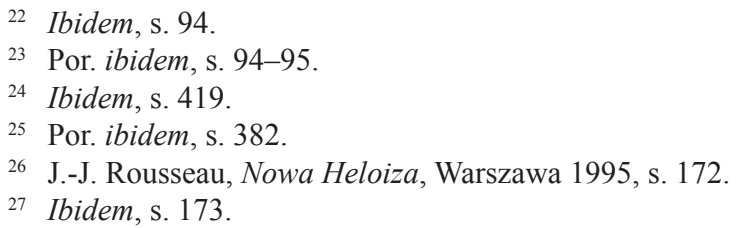


zbrojne), stając się państwem neutralnym, czyli bezstronnym i bezkonfliktowym, w którym można negocjować, porozumiewać się i dogadywać, dokonywać arbitrażu, prowadzić rokowania i konferencje, możliwe jest też podpisanie zawieszenia broni czy zawarcie traktatów pokojowych. Dzięki temu Szwajcaria, która konsekwentnie prowadziła i prowadzi taką politykę międzynarodową, niejednokrotnie stawała się niemal „utopijną wyspą” na oceanie świata, wokół której toczyły się wojny. A jednak była to wyspa prawdziwa.

Utopią jest więc świat przedstawiany bez wojen, armii, masakr, grabieży, gwałtów, zniszczeń, plądrowania, o którym pisał w Gwarancjach harmonii i wolności z 1842 r. niemiecki socjalista utopijny Wilhelm Weitling (1808-1871). Według niego ewidentną korzyścią płynącą ze wspólnoty, a związaną z rezygnacją z wojen, miało być wyeliminowanie wszelkich nieszczęść z nią związanych, takich jak np. rozkazy i pokorność, nienawiść i zawiść, duma i pycha, prześladowania i ucisk, niełaska, służba wojskowa, zajmowanie, plądrowanie, stałe armie, twierdze i więzienia, tyrania i psy gończe ${ }^{28}$. Przy czym na wypadek wojny Weitling zapowiada, że naród tworzący wspólnotę opartą na prawach natury będzie mieć zawsze przewagę nad swymi wrogami z kilku powodów. Po pierwsze, dzięki ożywiającemu wszystkich entuzjazmowi równości, który nawet z najbardziej lękliwego i najsłabszego człowieka uczyni bohatera. Po drugie, dzięki ogromnym środkom pomocniczym, ponieważ wszystkie siły zaoszczędzone w pracy mogą być wykorzystane do prowadzenia wojny, a rząd nie będzie musiał żebrać o kapitał u finansistów ${ }^{29}$. Po trzecie wreszcie, bardziej jako realista, a nie utopista zaproponował coś, co skutecznie uczyniła Rosja w czasie kampanii z Napoleonem w 1812 r. oraz Związek Radziecki w „wojnie ojczyźnianej” z III Rzeszą od czerwca 1941 r., mianowicie wszystko, co się dało, zostało albo wywiezione w głąb kraju, albo zniszczone w obawie przed tym, że może trafić w ręce najeźdźców. W ten sposób „w miarę zbliżania się wroga wycofują się zależnie od okoliczności albo do twierdz czy armii, ażeby je zasilić, albo też w głąb kraju - tak że wróg nie znajduje nic prócz opustoszałych wsi i miast, albo nawet $\mathrm{i}$ tego nie, jeśli to jest celowe" ${ }^{30}$. Najbardziej utopijne pozostaje jednak stwierdzenie Weitlinga, według którego właściwie „wszystko jest możliwe we wspólnocie, nawet prowadzenie wojny bez pieniędzy!’’31.

W powyższym kontekście znakomitym podsumowaniem utopijnych refleksji na temat wojny i pokoju może być cytat z innego dziewiętnastowiecznego socjalisty utopijnego Roberta Owena (1771-1858), który dość pesymistycznie stwierdził, że „gdyby wszystkich ludzi nauczono rozsądku, sztuka wojenna stałaby się bezprzedmiotowa"32.

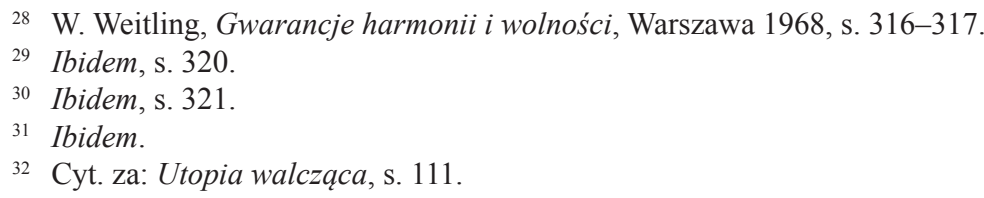




\section{SI VIS PACEM, PARA IUSTITIAM! - CZYLI O WNIOSKACH PŁYNĄCYCH Z UTOPII}

Generalnie mieszkańcy utopii nienawidzą wojen, mimo że czasem uznają je za konieczność ${ }^{33}$. Jeśli utopie wspominają coś o wojnie, to zawsze czynią to w kontekście pokoju jako celu każdej wojny, jak również ostatecznym celu życia w samych utopiach. Przesłaniem wszystkich utopii pozytywnych jest bowiem podkreślenie tego, że tylko mądrość jest gwarantem szczęścia, tak jak w przypadku prowadzenia wojen tylko mądrość jest gwarantem zwycięstwa. To ostatnie z kolei, jeśli nie będzie prowadzić do pokoju (najlepiej wiecznego), nigdy nie będzie uznane za pełne.

W utopiach można zatem znaleźć szereg rozwiązań i recept mówiących o tym, w jaki sposób ograniczyć wojny, a najlepiej całkowicie je wyeliminować. W pierwszej kolejności proponują znieść ich najczęstsze przyczyny, a te wynikają z niesprawiedliwości przejawiających się w różnych sferach życia społecznego ludzi. Przykładowo odnośnie do sfery życia ekonomicznego mówią o konieczności uspołecznienia własności i zniesienia jej formy prywatnej, w rezultacie kult złota i pieniądza (w tym nieustanne dążenie do pomnażania zysków) proponują zastąpić szacunkiem dla ludzi pracy oraz obowiązkiem rozwijania własnego człowieczeństwa. Na gruncie politycznym zachęcają do współpracy międzynarodowej na uczciwych warunkach, wyzbycia się rządzy władzy i panowania nad innymi oraz zrezygnowania z podbojów i zniewolenia. Wyżej od militarnych i siłowych cenią dyplomatyczne i sądowe sposoby rozwiązywania wszelkich konfliktów. W sferze kulturowej wymagają szacunku dla innych, w tym dla pokonanych, zwłaszcza jeśli znajdują się na niższym stopniu rozwoju. W swoich systemach edukacyjno-wychowawczych, mimo że przygotowują do wojny i walki, nacisk kładą na inne sposoby okazywania patriotyzmu. W najbardziej skomplikowanych pod tym względem sferach, czyli religijnej i moralnej, utopie godzą się jedynie na wojny z tzw. wyższych pobudek, w imię pewnych zasad i wartości, do obrony których są niejako zmuszone. O wiele lepiej niż w prawdziwych państwach krainy utopijne i ich mieszkańcy wcielają w życie zasady tolerancji religijnej i swobodnego rozwoju nauk. To wszystko dzieje się tak, ponieważ utopiści doskonale zdawali sobie sprawę z tego, że u podstaw wszystkich wojen, niezależnie od sfery życia społecznego ludzi, zawsze można znaleźć te same przyczyny, które się powtarzają. Filozofowie starożytni wiązali je z chorobami ludzkiej duszy, chrześcijanie - z grzechami głównymi, a zdrowy rozsądek określa je po prostu „złą wolą”. Wśród nich po dziś dzień znajdują się: strach, pycha, chciwość, nieczystość, zazdrość, gniew, lenistwo. Rozwój społeczeństw masowych przyczynia się szcze-

33 Por. F. Brandli, Guerre et paix, [w:] Dictionnaire critique de l'utopie au temps des Lumières, sous la direction de B. Baczko, M. Porret, F. Rosset, Genève 2016, s. 524. 
gólnie do potęgowania ich w tych ludziach, którzy nie potrafią sobie z nimi radzić. Wszystkie utopie jako takie za podstawę przyjmują właśnie społeczeństwa oparte na fundamencie wspólnotowego życia ludzi. Te w wersji pozytywnej radzą sobie z wszelkimi problemami - potrafią nie tylko pomóc potrzebującym jednostkom, ale przede wszystkim godzą ich interes z interesem ogółu, co jest największą trudnością. Natomiast utopie negatywne są prostsze w działaniu, a przez to bardziej kuszące dla świata realnego, gdyż nie znają innego rozwiązania problemów niż przez pozbycie się ludzi, którzy je generują.

W związku z tym, choćby nawet nie udało się wyeliminować przyczyn i skutecznie rozwiązać naszych problemów, należy nieustannie walczyć z nimi i nigdy się nie poddawać - taka wojna toczy się również w utopiach. Chodzi w nich bowiem o to, że możemy zorganizować sobie lepszy świat, w którym ostatecznie zwycięży i zapanuje pokój. A jeśli nie, to przynajmniej powinniśmy kontrolować wojny, minimalizować ich negatywne skutki, aby w każdym momencie ich trwania można było doprowadzić do jak najszybszego zakończenia konfliktu.

\section{BIBLIOGRAFIA}

Brandli F., Guerre et paix, [w:] Dictionnaire critique de l'utopie au temps des Lumières, sous la direction de B. Baczko, M. Porret, F. Rosset, Genève 2016.

Campanella T., Miasto stońca, Wrocław 1955.

Cicero, De Officiis (O powinnościach), [w:] idem, Pisma filozoficzne, t. 2, Warszawa 1960.

Fénelon F., Przypadki Telemaka Syna Ulisesa, Warszawa (Lipsk) 1775.

Frycz Modrzewski A., O poprawie Rzeczypospolitej, [w:] idem, Dzieła wszystkie, t. 1, Warszawa 1953.

Izdebski H., Historia myśli politycznej i prawnej, Warszawa 2001.

Kant I., Wieczny pokój, Torun 1992.

Kuźmicz K., Kantowska koncepcja wiecznego pokoju jako przykład idei jednoczacej ludzkość, [w:] Wielokulturowość polskiego pogranicza. Ludzie - idee - prawo, red. A. Lityński, P. Fiedorczyk, Białystok 2003.

Leszczyński S., Rozmowa Europejczyka z wyspiarzem z Królestwa Dumocala, [w:] Rys życia $i$ wybór pism Stanisława Leszczyńskiego króla polskiego xięcia Lotaryngii i Baru zwanego Filozofem Dobroczyńca, Warszawa 1828.

Mably G.B. de, Zasady praw, t. 1-2, Kraków 1952.

Morus T., Utopia, Poznań 1947.

Pacyfizm. Prawo a dzieje państwa i ustroju, red. M. Szyszkowska, t. 2, Białystok 2001.

Pacyfizm czy zagłada, red. M. Szyszkowska, Warszawa 1996.

Palacz R., Klasycy filozofii, Warszawa 1988.

Rousseau J.-J., Nowa Heloiza, Warszawa 1995.

Sentencje tacińskie, oprac. M. Dubiński, Warszawa 2005.

Sun Tzu, Sztuka wojny, Warszawa 2009.

Utopia walczaca, wyb. i oprac. R. Brandwajn, Warszawa 1962.

Wegecjusz, De re militari, III, www.thelatinlibrary.com/vegetius3.html [dostęp: 21.10.2018].

Weitling W., Gwarancje harmonii i wolności, Warszawa 1968. 


\section{SUMMARY}

Reflection on war and peace is inextricably linked to utopian thinking. In social utopias, war-related issues are one of the most realistic descriptions. However, peace is a universal value in Utopias. This is not only ideological issue, but also a destination that utopias are trying to achieve. The author, on the example of selected utopias from different periods, showed their anti-war message. It has a timeless character and is also valid in the $21^{\text {st }}$ century.

Keywords: pacifism; peace; utopia

\section{STRESZCZENIE}

Refleksja na temat wojny i pokoju jest nieodłącznie związana z myśleniem utopijnym. W utopiach społecznych kwestie dotyczące wojny stanowią jedne $\mathrm{z}$ najbardziej realnych opisów. Jednakże to pokój jest w utopiach wartością o charakterze uniwersalnym, stanowiącą nie tylko ich element ideowy, ale przede wszystkim cel, do którego dążą. Autor na przykładzie wybranych utopii $\mathrm{z}$ różnych epok ukazał ich antywojenne przesłanie. Ma ono ponadczasowy charakter i jest aktualne również w XXI w.

Słowa kluczowe: pacyfizm; pokój; utopia 